\title{
Influence of Information Technology, Organizational Communication, and Leadership Towards Employee Performance
}

\author{
Sarton Sinambela*, PJP Ginting, Erwin Marojahan Simanjuntak, Mochamad Agus Ridwan \\ Universitas Tantular University \\ Jakarta, Indonesia \\ *sartonsinambela@yahoo.com
}

\begin{abstract}
The research aims to find out how information technology, organizational communication, and leadership have influenced employee performance. The data analysis method used is multiple linear regression analysis. The sample used 168 respondents were determined. Data collection techniques are by distributing questionnaires directly to employees. The results of this research is information technology, organizational communication, and leadership has impact on employee performance.
\end{abstract}

Keywords-information technology, organizational communication, leadership, employee performance

\section{INTRODUCTION}

Information technology is often associated with computers and telecommunications. The effectiveness of the use of information technology will contribute so that tasks can be carried out properly. This can be obtained by utilizing information technology to reduce human errors, such as forgetfulness, decreased precision due to fatigue, and others [1].

Communication is the delivery and understanding of meaning, no group can survive without communication: the transfer of meaning between its members, only through the transfer of meaning from one person to another, information and ideas can be delivered. But, communication is more than just implanting meaning [2].

Meanwhile, according to Luthans, communication is an understanding of something unseen and hidden, this element is inherent in a culture [3]. However, equally important, communication is a personal process that includes the exchange of behavior [4].

Leadership broadly includes the process of influencing in setting organizational goals, motivating followers' behavior to achieve goals, influencing the interpretation of the events of their followers, organizing and activities the group [5].

Performance is the result of quality and quantity of work achieved by a person [6]. According to Rivai and Deddy
[5] stating performance is a real behavior that is displayed by everyone as a work achievement generated by employees in accordance with their role in the company. Furthermore, employee performance is defined as the ability of employees to perform certain skills [7].

\section{LITERATURE REVIEW}

\section{A. Information Technology}

The role of information technology in future life. Utilization of technology is related to the way companies and organizations plan and regulate information technology in achieving benefits, potential, and effectiveness. Computer networks have experienced very rapid development from year to year, for example the internet as a unifying media throughout the world has succeeded in increasing the number of its users from day to day. Efforts to improve market performance is affected by government interference through information and communication technology (ICT) [8].

Information technology is a combination of computer technology and communication technology, where computer technology is technology related to computers, including equipment related to computers and communication technology is technology related to long-distance communication [9].

Information technology which is usually identified with computers and telecommunications, which is a tool that can help humans communicate and convey information that is processed digitally with indicators: frequency of use, time of use, pattern of use, dependence, Efficient and effective [10].

\section{B. Communications}

Communication is element in culture which gives meaning to the visible communication process. However, equally important, communication is a personal process that includes the exchange of behavior. From the understanding of communication above, it can be concluded that communication is a process of understanding the meaning of each individual who communicates, henceforth the process of exchanging 
meaning between individuals so that what becomes an idea or ideas can be understood by the parties communicating [3].

\section{Leadership}

The notion of leadership, that is, an activity or art influences other people to want to work together based on the ability of that person to guide others in achieving the goals desired by the group. Leadership is a science that comprehensively studies on how to direct, influence, and supervise others to carry out tasks according to the planned instructions [11].

Leadership is a process of influencing group activities in the formulation and achievement of goals [12]. Leadership, can be concluded that as a process of directing and influencing activities that have to do with the work of group members. Leadership is a way a leader influences subordinates to want to work together and work effectively according to the rules of working with leadership indicators: ideal influence, inspirational motivation, intellectual stimulus and individualized consideration [13].

\section{Employee Performance}

Performance is the result of quality and quantity of work achieved by a person in carrying out tasks in accordance with the responsibilities given to him [6]. Employee performance, it concluded that the willingness of an individual to carry out activities or perfect them in accordance with their responsibilities with the results as expected, through a comparison between actual work results with work standards set with indicators as follows: time standards, cost standards, quality standards, behavioral standards and productivity standards [4].

\section{METHODS}

The data analysis method used is multiple linear regression analysis. The sample used 168 respondents were determined. Data collection techniques are by distributing questionnaires directly to employees.

The results of the validity test can appear that all indicators of each variable, namely information technology, organizational communication, leadership, and employee performance, are valid (r-count> 0.1506). Based on the results of the reliability test, the value of Cronbach's alpha on each variable of information technology, organizational communication, leadership, and employee performance is greater than 0.70 , so it can be concluded that all variables are reliable. Based on the results of normality testing, it is known that the Kolmogorov-Smirnov value is 0.064, and the significance is 0.094 . The significance value obtained is greater than 0.05 . Then it can be concluded that the data in the regression model is normally distributed.

\section{RESULTS AND DISCUSSION}

A. Results

TABLE I. RESULTS REGRESSION

\begin{tabular}{|l|l|l|c|}
\hline No & \multicolumn{1}{|c|}{ Variable } & \multicolumn{1}{|c|}{ T } & Sig. \\
\hline 1 & Information Technology & 2.874 & 0.005 \\
\hline 2 & Organizational Communication & 2.628 & 0.009 \\
\hline 3 & Leadership & 6.378 & 0,000 \\
\hline
\end{tabular}

Based on Table 1, results regression of information technology on employee performance generates with significant values $0.005<0.05$. Meanwhile, the beta coefficient value obtained is positive $(0.133)$, thus it can be concluded that the information technology variable has a significant positive effect on employee performance.

The results regression organizational communication on employee performance resulted significant values $0.009<$ 0.05 . Meanwhile, the beta coefficient value obtained is positive (0.139), it can be concluded that the organizational communication variable has a significant effect on employee performance.

The results of regression variables leadership to employee performance produces with significant value of $0,000<$ 0.05 . Meanwhile, the beta coefficient value obtained is positive (0.292), it can be concluded that the variable leadership significant effect on employee performance.

TABLE II. DETERMINATION COEFFICIENT TEST RESUlts

\begin{tabular}{|l|l|l|l|l|}
\hline Model & \multicolumn{1}{|c|}{ R } & R Square & \multicolumn{1}{c|}{$\begin{array}{c}\text { Adjusted R } \\
\text { Square }\end{array}$} & $\begin{array}{c}\text { Std. Error of the } \\
\text { Estimate }\end{array}$ \\
\hline 1 & $.833 \mathrm{a}$ & .693 & .688 & .25962 \\
\hline
\end{tabular}

a. Predictors: (Constant), Leadership, Information technology, Organizational communication

Source: Results of Data Processing

Based on Table 2, the test results of the coefficient of determination in obtained an Adjusted R-Square value of 0.688 or $68.8 \%$. This means that the variable Information Technology, Organizational Communication, and Leadership together provide an influence of $68.8 \%$ on the Performance of Employees.

\section{B. Discussion}

A significant positive effect of information technology on employee performance can be observed in the relatively high frequency of using information technology as an indicator of information technology. The relatively high use of information technology within the Presidential Secretariat can be understood by the many tasks of the Presidential Secretariat that must be carried out in a quick and timely manner. Because of the urgent task and relatively fast time that must be done makes use of information technology with high frequency. Because the use of information technology with high frequency is a determinant of employee performance and, 
information technology is a real need of the Presidential Secretariat to carry out its duties, so the influence of information technology that is significant on the performance of the staff is a condition that occurs.

In the meantime, the efficient use and effectiveness of the use of information technology as an indicator of information technology are directly related to the performance. Increasing the efficiency of the use of information technology by employees is conducive to increasing the performance of the employees. Likewise, increasing the effectiveness of the use of information technology by employees is conducive to producing an increase in the performance of the employees. Therefore, improving the performance of the employees is a condition that is preceded by an increase in the efficiency and effectiveness of the use of information technology.

The results of the second hypothesis show that the hypothesis was accepted as variables organizational commitment obtain a significant positive effect of organizational communication on employee performance can be observed from the suitability of the targets to be achieved and the objectives to be achieved together as indicators of organizational communication. The conformity of the targets to be achieved by each employee is a condition that precedes the performance. The achievement of the targets to be achieved by each employee, in turn, is the achievement of the performance targets of each employee, which cumulatively represents the performance as a whole.

Furthermore, the conditions that precede the performance of employees can be referred to as the suitability in the delivery of communication as well as adjustments in communication barriers as indicators of organizational communication carried out by employees. Conformity in the delivery of communication by employees means that all employees have conformity in communication to facilitate the achievement of employee performance both personally and institutionally. Therefore, the achievement of the performance of the employees is a condition that is preceded by the suitability in communicating by and among all employees.

Likewise, the adjustment in communication barriers made by the employees is an effort made by employees to find solutions in communication barriers that are possible to be created in carrying out personal tasks. The existence of a solution to communication barriers is a condition that precedes the achievement of the performance of the employees. Therefore, the achievement of the performance of the employees is a condition that is preceded by a solution to the communication barriers prepared and implemented by the staff.

Conformity with the state of communication in the environment is an effort made by all employees to adjust their communication to the conditions that actually exist in the communication conditions. Therefore, adjustments to conditions in communication are conditions that precede employee performance. So that the performance of the employees is a condition that requires adjustments to the conditions in communication.

Furthermore, the conditions that precede the performance of employees can be referred to as the existence of adjustments in fostering relations with superiors and suitability in achieving harmony in work as indicators of organizational communication carried out by employees of the Presidential Secretariat. Adjustment in developing relationships with superiors who do employees of the Secretariat of President is a step forward employee to produce the best work, especially when the supervisor well receives the adjustment. Therefore, there is an adjustment in fostering relationships with superiors, and the conditions are created, the employee will work well to produce optimal employee performance. Thus, the existence of adjustments in fostering relations with superiors by employees is a condition that precedes the performance of employees.

No less important is to make employees feel calm in critical situations as a leadership effort to maintain employee conditions at work. Conditions that are calm and maintain conditions that are calm at work are conditions that allow employees to produce optimal performance. Therefore, making employees feel calm in a critical situation as a leadership effort to maintain the condition of employees at work is a condition that precedes the performance of employees, including in the Presidential Secretariat.

Efforts to instill the values, ideals, and belief in employees conducted by the leadership will make employees work optimally their duties who get invested values, ideals, and beliefs from their leaders will be motivated to work optimally to produce optimal employee performance as well. These conditions reflect that efforts to instill the values, ideals, and beliefs in employees conducted by the leadership are conditions that precede the performance of employees.

In the meantime, leaders who pay full attention to employees are the ideal of every employee at work. Leaders who give full attention to employees make employees will be motivated to work optimally to produce employee performance. Thus, leaders who give full attention to employees are conditions that precede the performance of the employees. So it can be mentioned that the leader who gives full attention to employees influences the performance of the employees.

\section{CONCLUSION}

Based on the results of research and discussion, it gained some conclusions as information technology, organizational communication and leadership have a significant impact on employee performance. Meanwhile, leadership as the most dominant variable affecting employee performance to recommend that the practitioner be prioritized. 


\section{REFERENCES}

[1] H.B. Uno and N. Lamatenggo, Teknologi Komunikasi dan Informasi Pembelajaran. Jakarta: PT Bumi Aksara, 2011.

[2] S.P. Robbins and T. Judge, Perilaku Organisasi. Jakarta: Salemba Empat, 2015.

[3] F. Luthans, Perilaku Organisasi. 10th ed. Jakarta: Salemba Empat, 2010.

[4] R.W. Mondy and R.M. Noe, Human Resource Management. 10th ed. Jakarta: Erlangga, 2012.

[5] V. Rivai and M. Deddy, Kepemimpinan dan Perilaku Organisasi. Jakarta: PT. Raja G, 2011.

[6] A.P. Mangkunegara,Manajemen Sumber Daya Manusia Perusahaan. Bandung: PT. Remaja Rosdakarya Offset, 2010.

[7] L.P. Sinambela and S. Sinambela, Manajemen Kinerja: Pengolahan, Pengukuran dan Implikasi Kinerja. Depok: PT. Raja Grafindo Persada, 2019.
[8] M.R.I. Pratama, "The impact of double mediation on market performance using information communication technology and market orientation,” J Manaj dan Pemasar Jasa, vol. 13, no. 1, pp. 95-110, 2020.

[9] N.E. Husda and Y. Wangdra, Pengantar Teknologi Informasi. Jakarta: Baduose Media, 2016.

[10] W.H. DeLone and E. McLean, "The DeLone and McLean model ofInformation systems success : A ten-year update," J Manag Inf Syst. vol. 19, no. 4, pp. 9-30, 2003.

[11] I. Fahmi, Manajemen Kepemimpinan, Teori dan Aplikasi. Bandung: Alfabeta, 2017.

[12] Sedarmayanti, Manajemen Sumber Daya Manusia. 5th ed. Bandung: Rafika Aditama, 2011.

[13] B.M. Bass, B.J. Avolio, Y. Berson and D.I. Jung, "Predicting unit performance by assesing transformational and transactional leadership," J Appl Psycology, vol. 88, no. 2, pp. 207-18, 2003. 